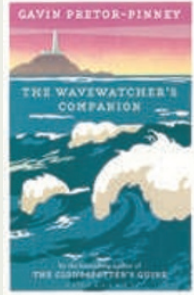

From ocean swells to heartbeats, waves are all around us. In The Wavewatcher's Companion (Bloomsbury, 2010), Gavin Pretor-Pinney marvels at undulations of all types, sharing an obsession that began while standing on a sea shore. As with his previous bestseller, The Cloudspotter's Guide, he peers with a perceptive eye at the phenomena of everyday life to reveal the science that underlies them. Along the way he ties together a vast range of topics, from the wiggle of a snake to the ripples of the Big Bang.

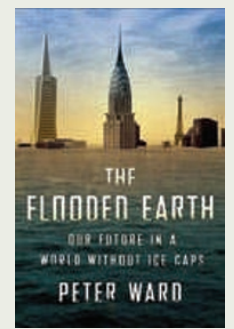

The unavoidable impacts of sea-level rise are imagined in astrobiologist Peter Ward's latest book. In The Flooded Earth (Basic Books, 2010), he cautions that the swelling of the oceans by up to 4 metres by the end of this century will be the most profound consequence of global warming. In coming decades, the ice caps will disappear, high salt levels will render prime agricultural land barren, and coastal cities, including Amsterdam, Miami and Venice, will have to be abandoned. Ward also notes the species extinctions that will result.

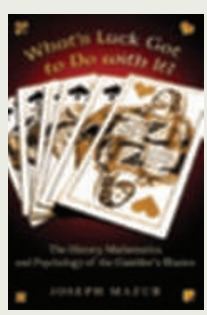

Mathematician Joseph Mazur examines the science of gambling in What's Luck Got to Do With It? (Princeton Univ. Press, 2010). From the dice-playing of Neolithic peoples to modern lotteries and casino capitalism, he tracks the history of placing bets. He explains both the mathematics of chance and the psychological and emotional factors that entice some people to risk it all to win that improbable jackpot.

\title{
A life both kind and strange
}

\author{
The Price of Altruism: George Price and \\ the Search for the Origins of Kindness \\ by Oren Harman \\ Norton/Bodley Head: 2010. 464 pp. \\ $\$ 27.95 / € 20$
}

The population geneticist George Price (1922-75) is an exception to the rule that scientists' lives make for dull reading. In The Price of Altruism, science historian Oren Harman lays bare the colour and pathos of Price's varied life, demonstrating that this irascible, unpredictable and self-centred man is worth a full-scale biography for his science as well as his psychopathology.

Price is best known today for his equation that extends William Hamilton's formulation of the genetic basis of kin selection - the tendency for individuals to foster and benefit from the reproduction of close relatives. Yet few evolutionary biologists know how altruism ultimately shaped Price's fate.

Price was, as Harman puts it, a real-life Forrest Gump, present at important historical turning points - the atomic bomb, the transistor, the computer - but never at the centre. He obtained a chemistry degree and $\mathrm{AhD}$ at the University of Chicago, Illinois, and worked on the Manhattan Project during the Second World War. Afterwards, he drifted between academic and industrial jobs. He did some biomedical research, got on the bandwagon early for computers and transistors, and tried to salvage the theatre lighting company that his long-dead father had started. Having published articles on science in popular magazines, he fancied that his main career was science journalism.

Price drifted personally too. His marriage, which produced two daughters, broke up after seven years, and he never had another stable relationship. Nor were his religious beliefs consistent. Only late in his life did he find out that his father was Jewish. For many years he was violently against religion, but in 1970 he became obsessed with reading the Bible.

By then, he was living in London. He had gone there in 1967 with no plans, but with money in his pocket from an insurance claim on a botched thyroid operation. The surgery left him with permanent incapacity and pain. This afflicted him in his later years, especially when he began to live

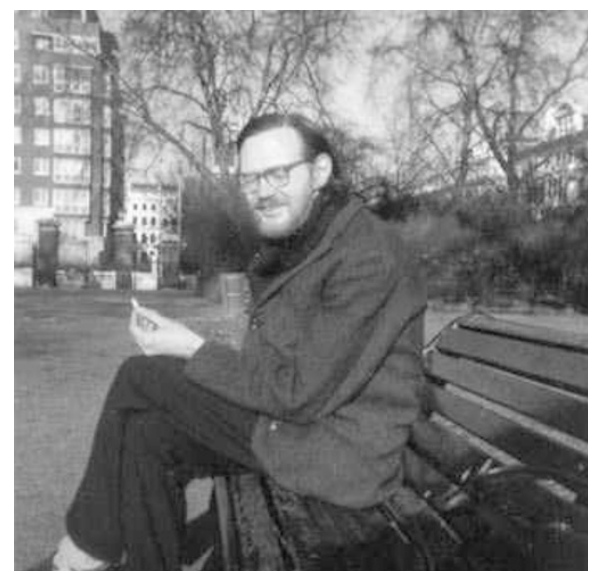

George Price in 1974, the year before his death.

rough after giving away all of his belongings in a fervent desire to help down-and-outs in London - the ultimate exercise in religious altruism. His few possessions had been accumulated through a remarkable event that changed the trajectory of his career.

Price spent his first months in London reading up on the evolutionary origins of altruism. He applied his mathematical skills to Hamilton's theory of kin selection, building into it a more general notion of evolutionary fitness. He took his results, uninvited, to Cedric Smith, then director of the Galton Laboratories at University College London. Smith was so impressed he gave Price an honorary association with his department and obtained fellowship support for him.

During the next few years, Price worked with geneticist John Maynard Smith to extend his application of game theory (based on the famous 'prisoner's dilemma') to natural selection. He derived the concept of the 'evolutionarily stable strategy', by which populations adopt strategies that maximize their capacity to deal with complex interactions between members of the group. Price developed Hamilton's kin-selection theory further, becoming especially close to him. Both Maynard Smith and Hamilton came to Price's funeral, the only mourners save for a few outcasts whom Price had befriended.

Price's standing in evolutionary theory is now secure, but he never lived to see this acceptance within the scientific community. He was accustomed to having his papers rejected by journals - including Nature, although most of his later ones were published there - and in receiving polite and perfunctory replies when he contacted the giants of disciplines that interested him. Harman makes good use of Price's 